\title{
When the dead are alive! The influence of the living dead in the letter of Jude
}

\author{
Stephan J Joubert \\ Department of New Testament Studies \\ University of Pretoria
}

\begin{abstract}
This essay investigates the impact of the deceased on the audience to which the letter of Jude was originally addressed. A construct of the influence of the "living dead" in ancient Babylon, Israel, the Graeco-Roman world and in African tradition serves as a basic cognitive map to come to terms with Jude's views on the dead. It is argued that, since the wicked dead, who are being physically punished in the underworld, are kept alive in the collective memory of Jude's community and since their deeds are re-enacted in the sinful behavior of intruders in their midst, their lives are influenced by the "presence" of these living dead. On the other hand and, although Jude does not deal with the physical whereabouts of the righteous death, he and his readers know that their postmortem honour is still intact. The righteous in this community is assured that God protects the integrity of the faithful dead.
\end{abstract}

\section{INTRODUCTION}

Ancient Mediterranean people knew that the world was filled with various forms of life. Gods, demons, angelic beings, powers, spirits and the souls of the dead occupied all available space. There was no void of any sort to be found anywhere. The universe was "full and perfectly replete with entities (corpora) of diverse form and quality and each having its own shape and dimensions" (Asclepius 33, in Malina \& Pilch 2000:79). It is no surprise then that the majority of people living in the Mediterranean world did not understand physical death as annihilation. The souls of the deceased continued to exist, albeit in shady, subterranean places such as Hades or Sheol. Although the corpses of the 
deceased were doomed to corruption, their souls remained alive, at least as long their bones remained intact, or while their memory was kept alive.

In this essay, the role and impact of the deceased on the audience of the letter of Jude is addressed. On the basis of a basic cognitive map, an overview of perceptions regarding the influence of the "living dead" (cf Mbiti 1969, for an African understanding of this concept) in ancient Babylonian, Israelite and Graeco-Roman societies (as examples of typical ancient Mediterranean culture), as well as in traditional African thought (as an example of a contemporary collectivist culture) is firstly presented, before Jude's views on the dead are dealt with. This is followed by a schematic construct of Jude's view of the role, fate and impact of the living dead.

\section{VISITING THE TERITORIUM OF THE LIVING DEAD}

In order to come to terms with the role, status and functions of the dead in the ancient Mediterranean world in general, and in the letter of Jude in particular, we need a cognitive map to make some sense of the available data. A quick journey to the realm of the dead in the ancient Mediterranean world, by means of the heuristic concepts "space" and "time" will, hopefully, provide us with the necessary key to understand the impact of the living dead on the group that Jude addresses in his letter. "Space and time," as the terms are employed here, relate to persons' efforts at control over and protection of the spatio-temporal locations that ideologically demarcate and define their group identity.

On a high level of abstraction ancient Mediterranean people accepted the continued presence of the dead as a given fact. In other words, these living dead, both individually and collectively, had the power not only to affect phenomena in the realm of the living, but also to exert direct influence over the lives and relationships of the living. Thus, the dead could delimit and assert control over certain geographical areas, individals and groups for specified or unspecified periods of time. On a lower level of abstraction at least two interpretations of the role and functions of the living dead in antiquity and in modern collectivistic cultures can be identified. Firstly, people, such as the Babylonians, and more recently, traditional Africans, understand the dead as existing post-mortem in the realm of sacred space. That is, they fill the invisible realm under the earth (the Babylonians), or the space close to their graves or former homes (African 
Religion) from where they exert a (mostly) positive influence on the living due to their direct contact with divine beings. This influence from beyond the grave continues at least for as long as the dead are remembered. Secondly, the ancient Israelites, Greeks and Romans understand the dead as existing in the realm of unclean, polluted space. This space is also fluid, since the dead can (sometimes) cross the porous boundary between the nether life and this life. However, they exist in a polluted realm, which strips them from their pre-mortem powers and honour.

\subsection{The living dead within sacred space}

\subsubsection{Ancient Babylon}

In ancient Babylonian society, the dead always exerted an influence on the living. When people died they entered the underworld, called Irkallu, "the Great City." Apparently the underworld consisted of three levels: a lower court for the gods, the middle part, which personified the waters, and an upper level for the spirits of the dead (Yamauchi 1998:33f). The dead were sometimes buried underneath their own houses. Since they were not to be disturbed, it was not strange "to bury them beneath the room that offered the highest degree of privacy; which in the Ancient Near Eastern house, is the bedroom" (Van der Toorn 1996:61). Regular offerings had to be made to ancestors, in particular to the deceased father of the house by the oldest son (Yamauchi 1998:30). Apart from the daily offerings of flour and water to the dead and the pronouncing of their names, solemn rites were performed for departed ancestors at the end of each month, during the time of lunar invisibility. All members of the family were expected to participate in this kispum; the purpose being communion and the maintenance of mutual good will between the living and the dead. An annual festival for the gods of the underworld and the dead was also held in the fifth month, Abum (August), which included a vigil during which lights had to be burned.

The invocation of the dead by their names formed a central rite of the cult of the

dead. The names of father and mother, grandfather and grandmother, as well as brothers and sisters, were mentioned in the standard kispum, while the rest of the ancestors were referred to as "family, kin or relatives" (Van der Toorn 1996:54). In this way it was 
ensured that the names and identity of the deceased did not perish. Piety towards the forefathers endowed the living with an identity that was anchored in the past. Since the deceased dwelled with the gods they could offer protection to the living, as well as discipline them.

\subsubsection{Traditional African religion}

The cornerstone of traditional African religion is the belief in ancestor spirits (cf Mbiti 1969; Theron 1987; Thorpe 1991). In order to become an ancestral spirit, a proper induction ceremony must take place after a person's death, called the ukubuyisa. People remain ancestor spirits as long as they are remembered by their descendants. Therefore, large families are important, in order for ancestral spirits to remain in a state of personal immortality. According to Mbiti (1969:83) they are then in the Sasa-period of the living dead. However, when ancestral spirits are eventually forgotten by their descendants, they pass into oblivion.

Ancestral spirits usually live at the burial place or close to or even in their homes. In Zulu homes they live in the umsamo, a part of the hut where food and drink are put out for them. As guardians of the family traditions these spirits often appear to the living in dreams or visions to warn them against danger or to reprimand them when they neglect certain duties (cf Theron 1987). Sacrifices in the form of food or beer must then be offered to appease them. In exchange for sacrifices and for being honoured, ancestral spirits provide their families with crops, fertility, good health and prosperity. However, when angered, they can also cause illness and misfortune. Although family members often seek the help of their ancestors through prayers, sacrifices or mediums such as witch doctors, they also fear them because of their ability to cause misfortune (Mbiti 1969:84).

\subsection{The living dead in polluted space}

\subsubsection{Ancient Israel}

The dead always played an important role in ancient Israel, as can be seen in the close link between the land and the ancestors, as well as in the social concern for the survival 
of the names of the deceased in genealogies. Although biblical documents have been cleansed of references to cults of the dead, the socio-religious framework within which such cults had their functions has left some literary traces behind (cf Van der Toorn 1996:206). Prohibitions against native Israelite practices, such as offering food to the dead (e g Deuteronomy 26:14), at least point to the enduring popularity of these rituals, which were apparently practiced up to the Roman period (cf Tobit 4:17, where reference is made to the placing of bread on the grave of the righteous). Archaeologists have found bowls and platters for foodstuff in Israelite tombs in every period of their history. Apparently, this food provided nourishment to the deceased in the afterlife. However, due to the centralization of the cult of JHWH in Jerusalem, all forms of contact with the dead were "officially" forbidden. Since the latter were in Sheol, they were no longer part of God's cult and, therefore, did not need any nourishment.

According to popular Israelite thought, the deceased went to the subterranean abode of Sheol, where they existed like shades in extreme weakness and bereft of all personality (cf Bauckham 1998a:80; Jarick 1999:24ff). Sheol was usually seen as the final resting place of all people, not just the wicked. Punishment for transgressions of God's law already took place during one's lifetime on earth in the form of an early death, no male offspring and a dishonorable name.

\subsubsection{The dead in the Graeco-Roman world}

According to popular hellenistic belief the souls of the dead went to Hades, the underworld, where, according to Homeric tradition, they existed as shadows (cf Iliad 1.35). Philosophers, such as Plutarch, believed that good men's souls ascended to heaven to live in eternal bliss, while impure souls hovered around in the air as ghosts (De Sera Numinis Vindicta 564A-B; cf also Bolt 1998:70). In order to establish communio with the dead, as well as to protect the living from them, sacrifices of wine, oil and food, such as bread and dried fruit, were brought to the graves of the dead. This was done by the Greeks on the third, seventh (or ninth) and thirtieth day after the death of a family member, and by the Romans on the ninth day as well as on each birthday of the deceased (Klauck 1995:74). ${ }^{1}$ At the gravesite the dead were orally summoned to eat and drink. As

1 Klauck (1995:74) identifies a twofold reason for these sacrifices to the dead, namely: "die Befriedung von Totengeistern und die Uberzeugung, Tote seien für ihre jenseitige Existenz auf die Ernährung seitens der Menschen angewiesen." 
part of the sacrifice to the dead, a furrow was usually dug on the western site of the grave and water and oil was poured into it. Sometimes bottomless cylindric vases were placed on graves as signals of the life giving water that flowed down into the realm of the dead. Apart from these meals and sacrifices an annual feast for the dead was celebrated in Athens at the end of February. Two feasts for the dead were held in Rome: the Parentalia for deceased parents in May, as well as the Lemuria for all dead family members.

\section{THE LIVING DEAD IN THE LETTER OF JUDE}

\subsection{Vilifying the intruders}

In order to come to terms with the role of the dead in the letter of Jude, some introductory remarks regarding the nature of the letter must first be made. The author (from now on referred to as "Jude") applies motifs and themes from Israelite texts, deemed authoritative by him and his audience, to prevent the latter from adjusting or changing the ideological boundaries of their life world. In particular, references to well-known historical figures and episodes from Israel's past are used in this short letter as "visual" representations of the values and behavioural patterns expected from the readers. On the basis of Jude's understanding of the principle of ideological similarity between present and past, which links his readers to the history of their forefathers, he relates their present situation to relevant narratives from Israel's "holy books". On the basis of this continuity, which existed throughout the various stages of history up to the present, the crisis in Jude's community can thus be solved by an appeal to God's dealings with their ancestors. According to his hermeneutic, all answers are to be found on the pages of Israel's history. It need only be discovered and applied properly.

The problem that Jude is addressing in this letter deals mainly with the intrusion of a group of people into his readers' community, who are holding on to opposing views

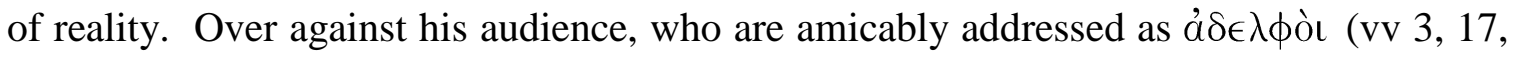
20 ), these intruders, probably a group of wandering teachers, are called $a \sigma \in \beta \in \hat{\imath} s$ (v 4). They reject Christ as Lord (v 4), sexually defile their bodies (v 8) and blaspheme (v 10). These icognito characters behave in the same manner as the notorious gallery of sinners from Israel's past, such as Sodom, Cain, Korah and Balaam (v 11; cf also Joubert 1995). 
However, the latter do not merely act as prefigurations, as "advance-presentations" of the false teachers in the readers' midst. These intruders are presented as the last in line within this infamous gallery of sinners in Israel's history. Thus, Jude does not find a "Steigerung" in terms of the correlation between the sinful types from the past and the antitypes in his community. He works the other way round by identifying the intruders with these "archetypes of sinful behaviour" whose bad reputation and eventual fate are documented in Israel's holy books (cf Joubert 1997:66).

\subsection{Two histories, two groups of people}

According to Jude, his readers are living in the final period of history. The presence of the false teachers in their midst is a clear sign that the end is at hand (vv 14-18). God's history with his people has already passed through various important phases, inaugurated by well-known figures and certain crucial epochs. In this regard Jude alludes to, or presupposes the time of Adam, ("the time of creation" - v 14), Enoch ("the time of the holy man as God's incontestable authority" - v 14), the patriarchs ("the time of God's new beginnings with his chosen people through Abraham" - v 7), Moses ("the time of the exodus from Egypt" - vv 6, 9), and the present, eschatological time of the Messiah, Jesus (v 4). However, these phases overlap with the activities of infamous sinners. As a matter of fact, a second type of history actually took shape and continued throughout Israel's salvation history. Therefore, the time of Adam overlaps with that of Cain, an archetype of sinful behaviour. In turn, the time of Enoch is associated with the behavior of the disobedient angels ("the Watchers") who did not keep to their divinely ordained boundaries (v 6). During the time of the patriarch Abraham, Sodom and Gomorrah and the cities on the Plain lusted after heavenly beings (v 7), while disobedient Israelites, such as Korah, transgressed God's laws during the time of Moses. Now, during the final phase of history, inaugurated by the Messiah, Jesus, the readers are once again confronted with intruders who hold on to beliefs that pose a threat to their own views.

According to Jude this final, Messianic, phase of history is fraught with extreme danger for the righteous. As a matter of fact, another history is currently taking shape in the readers' midst. This situation is so serious that the latter are reminded that "significant others" within the community, who played crucial roles in God's salvation history, 
namely the apostles (vv 17-18) and Enoch (vv 14-15), warned them beforehand about the coming of these dangerous intruders. However, the faithful may know that victory is assured, because throughout history God punished evildoers. At the same, time they are assured that God bestows eschatological glory on the righteous (vv 24-25). In Jude's community, as the culmination point of past and present, destruction and/or salvation now hinges on the readers' "correct" understanding of their place within history, be it the salvation history of God, or the "a-theistic" history of his enemies

\section{THE DEAD ARE NOT DEAD}

\subsection{The present fate of the wicked dead}

Apart from Jude's understanding of history and his community's place within it, he is also aware of the fate of the dead. This is clear from his reference in vv 5-7 to three groups of evildoers from the past that must now face divine judgment. In verse 5 the destruction of the disobedient Israelites in the wilderness is the topic of discussion. The verb ám心́$\lambda u \mu \iota$ employed here refers to their death as a visible sign of the wrath of God (BDAG 2000:118f). However, nothing is said of their eternal punishment; we only hear of these unfaithful Israelites' shameful (and permanent) removal from the presence of the righteous. In verse 6 Jude refers to the present suffering of the disobedient angels who abandoned their heavenly sphere of power. ${ }^{2}$ Jude is here dependent on 1 Enoch 6-19 (cf Bauckham 1983:50ff; Paulsen 1992:62f; Vögtle 1994:41). ${ }^{3}$ This section, from the Book of the Watchers, refers to their decent from heaven to have sexual relations with women

\footnotetext{
2 According to Knoch (1990:179), this term at the same time refers to the "Herschaftstellung und Herrschaftsbereich" of the angels. Since Jude and his readers were well versed in the Torah, but also in apocalyptic literature, such as (the original Aramaic version of) I Enoch and the Testament of Moses, he used references from these books in his argumentation, since they also functioned as holy books in his community.

3 There is uncertainty among scholars as to whether Jude used the Greek text of 1 Enoch or the Aramaic version of the Ethiopic text (cf Vögtle 1994:71ff). Bauckham (1983:94-96; 1990:139) is of the opinion that Jude knew the Greek version of 1 Enoch, but made his own translation from the Aramaic. However, the fact that Jude does not slavishly follow any known versions of 1 Enoch in his quotation from 1 En 1:9 in verse 14 at least points the fact "dass der Text des Jud eine eigene Textform repräsentiert" (Paulsen 1992:75).
} 
on earth. As a result these Watchers corrupted all of mankind in the time before the Flood. Therefore, they are presently "being kept" (cf the wordplay: Toùs $\mu \grave{\eta}$

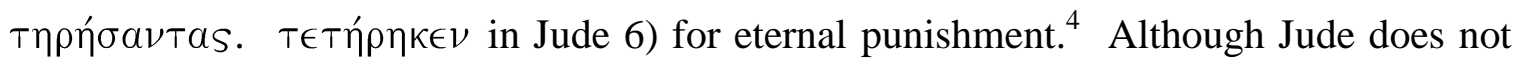

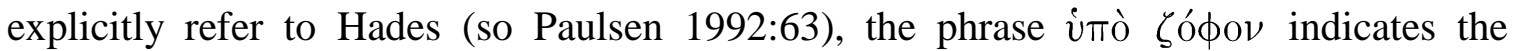
underworld (Bauckham 1983:53). But it is not only these supernatural beings that find themselves imprisoned in the dark spheres underneath the earth. Jude also knows of the inhabitants of Sodom and Gomorrah and the cities on the Plain who are presently experiencing the pains of the eternal fire (v 7).

Due to the sexual lusting of the cities on the Plain after strange flesh, Jude states

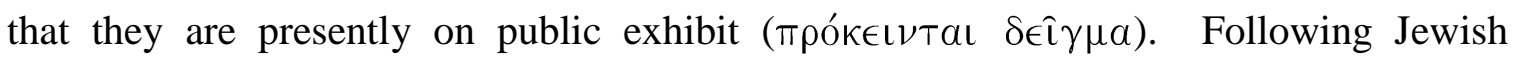
haggadaic tradition (cf, e g, Josephus [BJ 4.483] and Philo [Vit Mos 2.56]), he takes the wasteland around the Dead Sea as the historical cite of these ancient cities. To Jude this God-forsaken place, with its strong smell of sulphur, serves as proof of the presence of the eternal fire of hell underneath the earth. However, the smoking waste in the Dead Sea region not only points to the location, but also to the nature of the underworld as a place of permanent punishment, which commences directly after death.

Jude is well aware that the notorious gallery of sinners throughout Israel's history has not been annihilated after their death. Although the disobedient Israelites in the desert were removed from the presence of the righteous (v 6), they and other figures are still "alive," albeit in a different mode of existence in a location where they experience some form(s) of divine punishment. In the case of the Watchers, they are presently being kept in eternal chains in utter darkness (v 6), whereas the sinners from the cities on the Plain (v 7) undergo the pains of the eternal fire. Although Jude states that this punishment is in anticipation of the eternal sentence that will commence on the last day ( $\in$ is

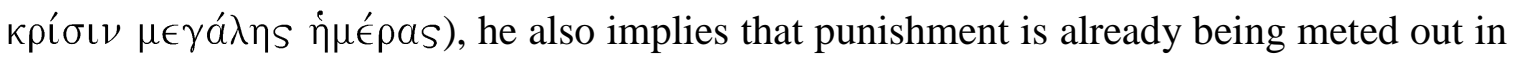
the subterranean abode. The wicked dead are not merely passively awaiting their future punishment (cf below).

\footnotetext{
${ }^{4}$ In 1 Enoch 10:4-6 and 13 we read how 'Asa'el is bound in the underworld, together with Semihazah and the Watchers.
} 


\subsection{One step further: The wicked dead as captives in the underworld}

In his role as "ein christliches Zeugnis der Henochliteratur" (Heiligenthal 1992:94), Jude is largely dependent on 1 Enoch for his views on the underworld. As Bauckham (1988b:49ff) has recently shown in a fascinating study, 1 Enoch (17-36) is the earliest extant work within Judaeo-Christian apocalypses, which deals with the so-called genre of "tours of hell". According to 1 Enoch 22, Sheol, as an interim spatial sphere under the earth, is a place of detention in the western corner of the earth where three categories of sinners await their final punishment. At the last judgment (cf 1 En 41:2) they will be cast into Gehenna, which is still under preparation (1 En 26:3-27:4). Together with the seven disobedient stars, the Watchers find themselves imprisoned in a dark abyss, the so-called second heaven, where they await their future punishment (1 En 22). However, in the Similitudes (1 Enoch 37-71), a later retelling of the Book of the Watchers (Himmelfarb 1993:59), we hear of the present punishment of these beings in the place underneath the waters, situated in the west (1 En 67). As is the case with the cities on the Plain, the smell of sulphur and the warm water in the region above the place of their punishment serve to locate it in the subterranean abode in the region of the Dead Sea.

Bauckham (1998b:70f) points out that the idea of the punishment of the wicked dead before the Day of the Lord developed gradually. According to him, it was probably a minority view in Judaeo-Christian works until well into the second century CE. He finds only one passage in the New Testament (Luke 16:19-31) that refers to the punishment of sinners immediately after death. However, the references to the fate of the dead in the letter of Jude (as a document from the second half of the first century CE) should probably also be understood in terms of active divine punishment. Jude's intention is not to imply that, although the righteous dead are not yet rewarded and the wicked dead are not yet punished, the former do already delight and the latter do already suffer in anticipation of their respective destinies. ${ }^{5}$ For instance, he knows that the Watchers are already

\footnotetext{
5 One Jewish document from this time, which understands death (that is, the death of the martyrs) as a direct transformation into God's glory, is 2 Maccabees (Powers 2001:199ff). The author of this work (c. 125-63 BCE - Bartlett 1973:215) supposess that a special resurrection of the righteous martyrs takes place immediately after their death (eg 2 Macc 7:36). In 2 Macc 15:12-16, Judas Maccabeus tells his warriors about a dream in which Onias appeared to him. Since Onias was already dead (cf 4:30-38), it seems correct to conclude, with Cavallin (1974:114): "Life in heaven immediately after death, or at least before the end of history, is apparently presupposed by the story of Judas' dream in 15:12-16." Cavallin (1974:45) also points out that the function of the resurrection of these Jewish martyrs is "the vindication of justice for the opressed and tortured righteous."
} 
bound in eternal chains, the same (type of) chains that will keep them imprisoned after the final judgment (cf also 1 En 10:4,11-12; 18:16). In terms of temporal and spatial categories, this image signifies their permanent immobilization. It denotes the termination of their supernatural powers and negative influence on people. At the same time, Jude's reference to the darkness, which enfolds all these beings (cf also 1 Enoch 10:4; 18:14), also serves as a "Beschreibung des Gerichtszuständes" (Heiligenthal 1992:76).

The present suffering of the cities on the Plain is also stressed in verse 7 . In typical ancient Mediterranean fashion Jude focuses on the inhabitants of these cities, not on the physical structures $\mathrm{f}$ these cities. In other words, the signs of smoke, warm water and sulphur in the region of the Dead Sea serve as proofs of the present suffering of their inhabitants. This ontological suffering of the sinners underneath the earth, as expressed in the visible signs in nature above, must warn the present generation of the eternal punishment that awaits the enemies of God in the near future.

In a so-called "already/not yet" schema, implicit in vv 5-7, Jude stresses that the disobedient dead are prisoners in the underworld where they ("already") experience preliminary forms of punishment in anticipation of the day of judgment ("not yet"), when the full force of God's wrath will be meted out. But the good news for the faithful is that these "living dead" cannot in any way cause them harm. The chains, darkness and fire referred to in vv 6-7, do not merely illustrate the present and future fate of the disobedient dead, it also acts as an assurance to the righteous that they are safe from the influence of their forefathers' enemies from beyond the grave. The wicked dead are completely stripped from their destructive powers and from any pre-mortem honour that they might have possessed. Therefore Jude's readers do not need protective amulets, chants or magical spells to guard them. God is protecting his people during this final stage of history.

\subsection{What about the righteous dead?}

Jude does not explicitly refer to the fate of God's people after death. At best we may infer from verse 9 (where the conflict between Michael and the devil over the body of Moses is described) that God serves as defender of his people's ascribed honour even 
after their death. ${ }^{6}$ Any slander brought against the faithful dead, such as the challenge posed by Satan against Israel's great leader, is seen by Jude as a challenge to God's honour. In the game of challenge-riposte between Satan and the archangel Michael regarding the burial of the body of Moses, the latter did not personally reject the devil's malicious slander. Instead, he appealed to God's judgment (cf Bauckham 1983:60f; Neyrey 1993:65). Jude thus presents God as the one who intervenes to protect the good name of the faithful, in life and in death. As the judge and supreme authority in the universe only he has the power to dismiss Satan's accusations against the righteous dead.

Although Jude does not deal with the physical whereabouts of the righteous death, he knows that their honour is still intact; their name will live on forever. Over against the wicked enemies, who experience permanent rejection and isolation in Sheol, the righteous at least continue to exist post-mortem by means of their good name. Jude's readers are thus assured that God protects the integrity of the faithful dead. Therefore, the righteous from the pages of Israel's holy books serve as ideal types, as "living examples" to be imitated by Jude's community.

Jude's community need not fear the dark snares of Hades. Since they belong to the final, eschatological generation of the Messiah, they are exhorted in verse 21 to

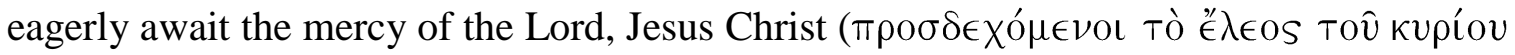
$\dot{\eta} \mu \omega \hat{\omega} \nu . .$.$) . Since the faithful, both living and dead, will receive mercy and new life in the$ not too distant future, Jude's community must remain steadfast during this dangerous time, especially since people who are devoid of the Spirit are active in their midst (vv 1723). Fortunately, they have the divine assurance that they will be protected from the

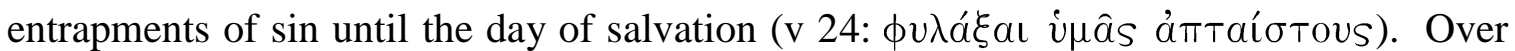
against the Watchers, who did not keep to their heavenly sphere and who are now kept in utter darkness for the final judgment ( $\uparrow \uparrow \in \hat{\imath} v-\mathrm{v} 6$ ), the community of Jude will soon be

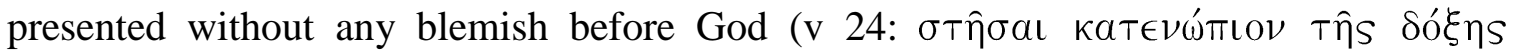

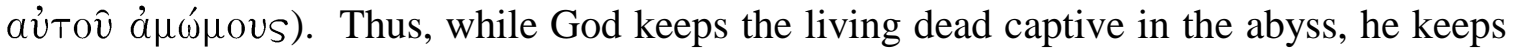
the faithful living obedient to himself so as to present them as living sacrifices without blemish on the coming day of judgment/salvation.

${ }^{6} 1$ Enoch 22:9 states that the righteous dead also await the final judgement in the underworld. But there is a clear distinction between them and the wicked. While the latter are kept in three dark holes, according to the types of sins they committed on earth, a fountain of clear water comforts the righteous in anticipation of their salvation on the day of the Lord. 


\subsection{The influence of the living dead}

According to Jude, death does not imply annihilation. The dead continue to exist, albeit in different spatial locations. However, no special offerings or rites are required in order to establish communion or mutual goodwill between the dead and the living. Jude knows nothing of a cult of the dead. In his view the living dead can neither harm nor protect the living, but they do exert some influence from beyond the grave. For instance, the sinful nature of the wicked dead is continued and reflected in the behaviour of the intruders into Jude's community. Although these intruders are not personal reincarnations of the notorious sinners from Israel's past, knowledge relating to the deeds of the wicked from the pages of history provides the community with a picture of the threat, which these intruders pose. These shady figures portray the same sinful characteristics as their forefathers. Although Jude does not find a "Steigerung" (in terms of a type-antitype schema) between the sinners from the past and the intruders, these sinners serve as the culmination point of the wickedness of all of their forefathers. In this sense they are the "living manifestation" of the notorious gallery of the wicked dead from Israel's past. Hermeneutically, Jude understands the impact of the living dead on the false teachers in the midst of his community in a twofold manner:

- The false teachers in Jude's community belong to the infamous gallery of sinners from history whose reputation has been clearly established. The names, wicked deeds and eventual fate of these sinners are kept alive through the community's retelling of the foundational narratives from their holy books. According to Jude the icognito intruders into his community reveal the same characteristics as their wicked forefathers who are now God's prisoners in the realm of the dead. Put differently, they belong to the same species of notorious sinners who played leading roles in the a-theistic history that took shape alongside God's dealings with his people.

- Jude's opponents combine all the wicked traits of their notorious forefathers. In the words of verse 11: these intruders follow in the footsteps of a Cain, a Core and a Balaam. Although the wicked dead are permanently imprisoned in Sheol, their collective sinful nature has been "revitalized" or "reborn" in Jude's opponents. 
Therefore, the latter at the same time present themselves in the guise of a Cainredivivus, a Core-redivivus, a Balaam-redivivus, etc.

To the extent that the identity and behaviour of the wicked dead are kept alive in the collective memory of Jude's community, and are also re-enacted in the deeds of the intruders, their lives are influenced by the "presence" of the living dead. Over against the negative impact of the wicked dead on the community, Jude also hints at the positive influence of the righteous dead in their lives. For instance, the holy man Enoch has warned them long ago against these sinners (v 14). Through his book his voice may still be heard from beyond the grave.

Jude provides us with a basic framework for the understanding of the role of the dead in within the circles of apocalyptic followers of the Messiah, Jesus. This confirms our initial assumptions concerning the living dead (as spelled out in section 1 above). Jude's perspectives on the living dead could be schematized as follow:

\section{The wicked dead}

\section{Personae}

a. Disobedient angels (the Watchers).

b. Sinners who rejected God's commands throughout all phases of Israel's history.

\section{The righteous dead}

Personae

a. People obeying God's commands throughout Israel's history.

\section{Spatial location}

The dark abyss/Sheol (probably located under the Dead Sea).

Present fate (liminal phase)

a. The Watchers: preparatory punishment (eternal chains, darkness).

b. The wicked: (a foretaste of) the fire of hell.

\section{Spatial location}

Unknown (asleep in God's presence?).

\section{Present fate (liminal phase)}

No punishment. God as supreme judge and patron protects their honour in death. 


\section{Future fate}

In the coming aeon commencing on the day of God's final judgment: eternal punishment in Gehenna.

\section{Influence on the living}

No direct influence. The wicked dead are spatially imprisoned in Sheol until the day of the Lord. However, indirectly they exert influence through the presence of the false teachers who reflect all their character living. traits.

\section{Future fate}

After the day of salvation: permanent life in the new aeon with the Messiah, Jesus.

\section{Influence on the living}

No direct influence. However, they are indirectly present in the narration and reenactment of their exemplary deeds. Their deeds serve as models to be imitated by the

\section{CONCLUSION}

Jude is in a position to guide his readers through the various phases of Israel's history in order to point them to their central place in history as part of the final Messianic generation. At the same time he also takes them on a tour to the unseen world of the living dead. Jude knows that the dead are divided into two categories: the wicked and the righteous. Fortunately, his community need not fear the wicked dead since they are imprisoned in Sheol. Therefore, they cannot actively participate in the lives of Jude's community. But, although the dead are not intermediaries who possess the power to affect the living directly, they still do exert some influence. Through Jude's recollection of the pre-mortem deeds of the wicked dead ( $\mathrm{cf} v \mathrm{vv} 5-7 ; 11$ ), they are kept alive. Therefore, the dangerous presence of the dead is experienced in the activities of the intruders into the community who belong to the same species as they. In similar fashion, references to the pre-mortem deeds of the righteous dead also serve to keep them alive, particularly when the readers imitate their godly deeds, which are also recorded in Israel's official narratives.

Over against numerous ancient Mediterranean groups, where rituals, such as the feeding of the dead, ensured mutual goodwill and positive interaction between the living and the dead, Jude invites (the memory of) the living dead into his community through 
his references to Israel's foundational narratives. Amongst others, his references to and cryptic retellings of these stories, serve as a "legitimate" substitute for ritual practices related to the dead in contemporary Mediterranean culture.

Finally, Jude's concern with the deeds and the fate of the ancestors of his community endows the latter with an identity that is anchored in the past and in the unseen metaphysical world. Only through their active participation in God's salvation history, which is now in its final phase, the righteous will ensure that they do not fall into the dark snares of Hades - a fate that surely awaits Jude's opponents.

\section{Works consulted}

Bartlett, J R 1973. The first and second books of the Maccabees. Cambridge: University Press.

Bauckham, R J 1983. Jude, 2 Peter. Waco: Word. (WBC 50.)

Bauckham, R J 1990. Jude and the relatives of Jesus in the early church. Edinburgh: T \& T Clark.

Bauckham, R J 1998a. Life, death and the afterlife in Second Temple Judaism, in Longenecker, R (ed), Life in the face of death, 80-98.

Bolt, P G 1998. Life, death, and the afterlife in the Greco-Roman world, in Longenecker, $\mathrm{R}$ (ed), Life in the face of death: The resurrection message of the New Testament, 51-79. Grand Rapids: Eerdmans.

Bauckham, R J 1998b. The fate of the dead: studies in Jewish and Christian apocalypses. Leiden: Brill.

Cavallin, H C C 1974. Life after death: Paul's argument for the resurrection of the dead in 1 Cor 15. Part 1: An inquiry into the Jewish background. Lund: CWK Gleerup. (CB.NT 7/1.)

Heiligenthal, R 1992. Zwischen Henoch und Paulus: Studien zum theologiegeschichtlichen Ort des Judasbriefes. Tübingen: Francke. (TANZ 6.)

Himmelfarb, M 1993. Ascent to heaven in Jewish and Christian apocalypses. Oxford: Oxford University Press.

Jarrick, J J 1999. Questioning Sheol, in Porter, S E, Hayes, A., \& Tombs, D (eds), Resurrection, 22-31. Sheffield: Sheffield Academic Press. (JSNT S 186.)

Joubert S J 1995. Persuasion in the letter of Jude. JSNT 58, 75-87. 
Joubert, S J 1997. Facing the past. Transtextual relationships and historical understanding in the letter of Jude. BZ 22, 56-70.

Klauck, 1995. H J 1995. Die religiöse Umwelt des Urchristenbtums, I: Stadt und Hausreligion, Mysterienkulte, Volksglaube. Stuttgart: Kohlhammer. (KThS 9, 1.)

Knoch, O 1990. Der erste und zweite Petrusbrief. Der Judasbrief. Regensburg: Friedrich Pustet. (Regensburger Neues Testament.)

Longenecker, R N (ed) 1998. Life in the face of death: The resurrection message of the New Testament. Grand Rapids: Eerdmans.

Malina, B J \& Pilch, J 2000. Social science commentary on the book of Revelation. Minneapolis: Fortress.

Mbiti, J S 1969. African religions and philosophy. London: Heinemann.

Moxnes, H. 2001. Kingdom takes place. Transformations of place and power in the Kingdom of God in the Gospel of Luke, in Pilch, J (ed), Social scientific models for interpreting the New Testament. Essays by the Context Group in honor of Bruce J. Malina, 176-209. Leiden: Brill.

Neyrey, J H 1993. 2 Peter, Jude. A new translation with introduction and commentary. New York: Doubleday. (AncB 37C.)

Paulsen, H 1992. Der zweite Petrusbrief. Der Judasbrief. Göttingen: Vandenhoeck. (KEK 12/2.)

Powers, D G 2001. Salvation through participation: An examination of the notion of the believers' corporate unity with Christ in early Christian soteriology. Leiden: University Press.

Theron, P 1987. Die kerk en tradisionele swart gebruike. Pretoria: ISWEN.

Thorpe, S A 1991. African traditional religions: an introduction. Pretoria: University of South Africa.

Van der Toorn, K 1996. Familial practice in Babilionian, Syriac and Israelite culture. Leiden: Brill.

Vögtle, A 1994. Der Judasbrief. Der zweite Petrusbrief. Neukirchen-Vluyn: Neukirchener Verlag. (EKK 22.)

Yamauchi, E 1998. Life, death and the afterlife in the Ancient Near East, in Longenecker, R (ed), Life in the face of death: The resurrection message of the New Testament, 21-50. Grand Rapids: Eerdmans. 